\title{
Infectious salmon anaemia virus in wild fish from Scotland
}

\author{
R. S. Raynard*, A. G. Murray, A. Gregory \\ Fisheries Research Services (FRS) Marine Laboratory, PO Box 101, Victoria Road, Aberdeen AB11 9DB, Scotland, UK
}

\begin{abstract}
Following the outbreak of infectious salmon anaemia (ISA) at salmon farms in Scotland, UK, a survey was established to determine the extent of infection in wild fish. All fish tested were free from the clinical symptoms of ISA. Isolations of ISAV were made from 5 sea trout within areas where ISA affected salmon farms were located. Evidence for ISAV in other sea trout was provided by ISA RT-PCR diagnostic tests. Results from ISA RT-PCR tests reveal evidence for ISAV being present in salmon parr, adult salmon and juvenile brown trout in rivers distant from salmon farms and indicate that, at the time of the survey (1998-1999), ISAV may have been widely distributed. Nucleotide sequence analysis of segments 2 and 8 showed that for most sequences from wild fish there was $100 \%$ homology with ISAV isolated from clinically affected farmed fish although evidence is presented which indicates variability in ISAV sequences from wild fish. Modelling the RT-PCR findings indicates that ISAV among salmonid fish was spatially non-random. Brown trout, sea trout and salmon (adult and parr) show a pattern of occasionally large numbers of positive samples against a background of very low numbers.
\end{abstract}

KEY WORDS: Infectious salmon anaemia virus (ISAV) - Wild fish · Atlantic salmon · Sea trout · Nucleotide sequencing

Resale or republication not permitted without written consent of the publisher

\section{INTRODUCTION}

Infectious salmon anaemia (ISA) is a viral disease of marine Atlantic salmon Salmo salar first recognised in Norway (Thorud \& Djupvik 1988, Evensen et al. 1991). The disease is characterised by severe anaemia, leucopenia, ascites and haemorrhagic liver necrosis (Thorud \& Djupvik 1988, Evensen et al. 1991). ISA has, to date, been confined to salmon in marine farms or hatcheries using seawater without disinfection with the exception of one report of ISA in first feeding fry at a Norwegian hatchery which did not use seawater (Nylund et al. 1999). In Norway, the aetiological agent was identified as an orthomyxovirus-like enveloped virus (Hovland et al. 1994, Nylund et al. 1996) with an RNA genome consisting of 8 segments (Mjaaland et al. 1997). Krossøy et al. (1999) proposed that ISAV be clas-

*E-mail: raynardr@marlab.ac.uk sified in the family Orthomyxoviridae in a new genus, Aquaorthomyxovirus. Recently, this virus has been identified as the causative agent of ISA in Canada (Mullins et al. 1998, Bouchard et al. 1999, Lovely et al. 1999), and Scotland (Bricknell et al. 1998, Rodger et al. 1998, Stagg et al. 1999, Turnbull 1999). Segments 2 and 8 of the ISAV genome have been characterised, and significant differences in the nucleotide and amino acid sequences from North America, Norway and Scotland have been found (Blake et al. 1999, Cunningham \& Snow 2000, Inglis et al. 2000). The Scottish isolates are more closely related to Norwegian than the Canadian strains (Cunningham \& Snow 2000, Inglis et al. 2000).

The occurrence of ISA in Scottish farmed salmon has raised concerns about the prevalence of ISAV in the wider aquatic environment and in particular the potential role of wild fish in the epidemiology of this disease. There are no previous reports of wild sea trout or brown trout acting as carriers of ISAV although there 
is experimental evidence that brown trout and sea trout have the potential to act as carriers of ISAV (Nylund \& Jakobsen 1995, Nylund et al. 1995). In these experiments, clinical disease was not observed in the brown trout or sea trout, but there was a transitory drop in haematocrit and ISAV was transmitted from salmon to trout and from trout to salmon via the water route during cohabitation. Nylund \& Jakobsen (1995) demonstrated that ISAV could survive for 7 mo after challenge of sea trout and that sea trout may act as long-term carriers of the virus.

While there is good evidence that salmonid fish are capable of acting as carriers of ISAV, there is no evidence of non-salmonid fish species acting as potential vectors. Hjeltnes (unpubl., referred to by Nylund \& Jakobsen 1995) investigated the susceptibility of wrasse Ctenolabrus rupestris and Centrolabrus exoletus and turbot Scophthalmus maximus to ISAV but failed to demonstrate evidence of infection or carrier status in laboratory challenge.

Shortly after the diagnosis of the first occurrence of ISA in Scottish farmed salmon in 1998 (Rodger et al. 1998) a survey of wild fish in Scottish waters for evidence of ISA disease and ISAV was established. This paper reports the results of that survey to determine whether wild fish were affected by, or were carrying, ISAV and to compare nucleotide sequences of ISAV within wild fish populations and with the isolates from farmed salmon connected with the outbreak in Scotland.

\section{MATERIALS AND METHODS}

Wild fish survey. The survey was carried out during the period May 1998 to December 1999. Adult salmon were caught by bag net or were provided following holding in freshwater and stripping at wild fish hatcheries. Salmon parr and juvenile brown trout were obtained by electrofishing riverine habitats. Sea trout were fished from the estuaries of rivers and in the sea and were mostly caught by gill netting or by rod and line. Non-salmonid fish were caught by demersal trawl. Table 1 shows the numbers of fish of each species tested. Fish were examined for gross clinical signs of ISA (Stagg et al. 1999).

Tissue sampling for virology. Non-salmonid fish species: Samples of heart, kidney, liver and spleen
Table 1. Species and number of fish tested

\begin{tabular}{|llr|}
\hline Species & Common name & No. tested \\
\hline Scyliorhinus canicula & Lesser spotted dog fish & 4 \\
Raja clavata & Thornback ray & 35 \\
Clupea harengus & Herring & 153 \\
Sprattus sprattus & Sprat & 176 \\
Ciliata mustela & 5 bearded rockling & 21 \\
Melanogrammus aeglefinus & Haddock & 266 \\
Merlangius merlangus & Whiting & 152 \\
Trisopterus esmarki & Norway pout & 229 \\
Trisopterus minutus & Poor cod & 79 \\
Merluccius merluccius & Hake & 86 \\
Lophius piscatorius & Angler (monk) & 1 \\
Pleuronectes platessa & Plaice & 48 \\
Solea solea & Sole & 30 \\
Zeus faber & Dory (John dory) & 1 \\
Eutrigla gurnardus & Grey gurnard & 18 \\
Aspitrigula cuculus & Red gurnard & 30 \\
Myoxocephalus scorpius & Short-spined sea scorpion & 2 \\
Agonus cataphractus & Hook-nose pogge; armed bullhead & 1 \\
Callionymus lyra & Dragonet & 6 \\
Pomatoschistus microps & Common goby & 2 \\
Lepidorhombus whiffiagonis & Megrim & 25 \\
Zeugopterus punctatus & Topknot & 1 \\
Hippoglossoides platessoides & Long rough dab & 21 \\
Limanda limanda & Common dab & 20 \\
Micromesistius poutassou & Blue whiting & 40 \\
Salmo salar & Atlantic salmon & 423 \\
Salmo trutta & Brown trout and sea trout & 337 \\
& & \\
\hline
\end{tabular}

were placed into serum free media for ISAV isolation (Dannevig et al. 1995) and transported to the laboratory chilled on ice. Samples from up to 5 fish were pooled for virus testing. Some tissues were frozen as pools from 10 fish in liquid nitrogen.

Salmonid species: Adult salmon and sea trout were sampled individually while salmon parr and juvenile sea trout were sampled as pools of 5 fish by the same method as the non-salmonid species and transported chilled on ice.

Tissue sampling for RT-PCR. A piece of kidney was placed in RNA later ${ }^{\mathrm{TM}}$ (Ambion Inc, Austin, TX, USA). Samples from fish were tested either individually or pooled (5 fish to a pool) as described for tissue sampling for virology.

Virus culture. Sample tissues were screened for ISAV by culture on salmon head kidney cells (Dannevig et al. 1995) using 2 passes. Virus isolations were confirmed as being ISAV by immunofluorescence using the monoclonal antibody 3H6F8 (Falk et al. 1998) and RT-PCR (Mjaaland et al. 1997).

RT-PCR. RNA was extracted using TriZol (Life Technologies, Paisley, UK) according to the manufacturer's instructions. ISAV was diagnosed in samples by amplification of a $155 \mathrm{bp}$ fragment of segment 8 of the virus, as described by Mjaaland et al. (1997).

For 6 geographical locations where ISAV was diagnosed, an $878 \mathrm{bp}$ portion of segment 8 was amplified 
directly from kidney cDNA or from cultured virus, using the method described by Cunningham \& Snow (2000). Segment 2 was amplified in 2 overlapping fragments using 2 primer sets as described by Cunningham \& Snow (2000). An additional 10 cycles were added to the RT-PCR method described by Cunningham \& Snow (2000), to increase the possibility of detecting low levels of virus from wild fish.

Cloning. Segment 8 and the 2 fragments of segment 2 were cloned using the pGemT easy vector system (Promega, Southampton, UK) following manufacturers instructions. When cloning was used, 3 clones were sequenced from each sample.

Nucleotide sequencing. DNA was prepared for sequencing and analyses as described by Cunningham \& Snow (2000). Reactions were carried out using dRhodamine ${ }^{\mathrm{TM}}$ or Bigdye ${ }^{\mathrm{TM}}$ terminator fluorescent dyes and electrophoresis on an ABI 377 (Perkin Elmer, Warrington, UK). A minimum of 4 sequencing reactions was performed for each sample.

The sequences determined in this study were compared with sequences of segment 8 (AJ242016) and segment 2 (AJ242808) from an isolate of ISAV (390/98) which originated from a clinical outbreak of ISA on a salmon farm in Loch Nevis on the west coast of Scotland. Nucleotide sequence analysis of segments 2 and 8 of all isolates of ISAV made from clinical outbreaks in Scotland are identical to 390/98 (Cunningham \& Snow 2000).

Modelling the RT-PCR results. ISAV RTPCR results appear to be concentrated at certain sites and absent, even from large samples, taken at other sites. We use a simple model to obtain detailed understanding of the distribution of ISAV in order to estimate exactly how widespread the virus is. Analysis of the distribution of RTPCR-positive results is complicated because the sample sizes vary substantially (from 1 to 60 fish). The distribution has, therefore, been modelled by looking at levels of infection that give the observed prevalence among samples and the correct mean number of RT-PCR-positive samples.

Three models were applied, 2 assumed random distribution of ISAV between fish, regardless of their source, the third assumed a non-random distribution in which ISAV is present in some samples at a high frequency but absent from others. The 2 versions of the random model were fitted first to obtain the correct prevalence, i.e. number of samples containing at least 1 ISAV-positive fish and second to obtain the correct proportion of infected fish across all the samples.

Because sample sizes were variable, it was necessary to apply the models using the sample sizes obtained. The probability of 1 or more RT-PCRpositive fish being present in a sample was determined $\left(1-\mathrm{e}^{(1-p F)}\right)$, a fraction $\left(1-\mathrm{e}^{[1-p(F-1)]}\right)$ of this had at least 2 positive samples and so on. Here $F$ is the number of fish in the sample and $p$ is the probability per fish that 1 fish in the sample will be RT-PCR-positive. Values for these parameters that apply under the 3 sets of assumptions discussed are presented in 'Results'.

\section{RESULTS}

\section{ISAV diagnostic tests}

The geographical locations where fish were sampled are shown in Fig. 1. The number of fish tested and the number of positive results for each ISA diagnostic test are shown in Table 2. The locations where fish were

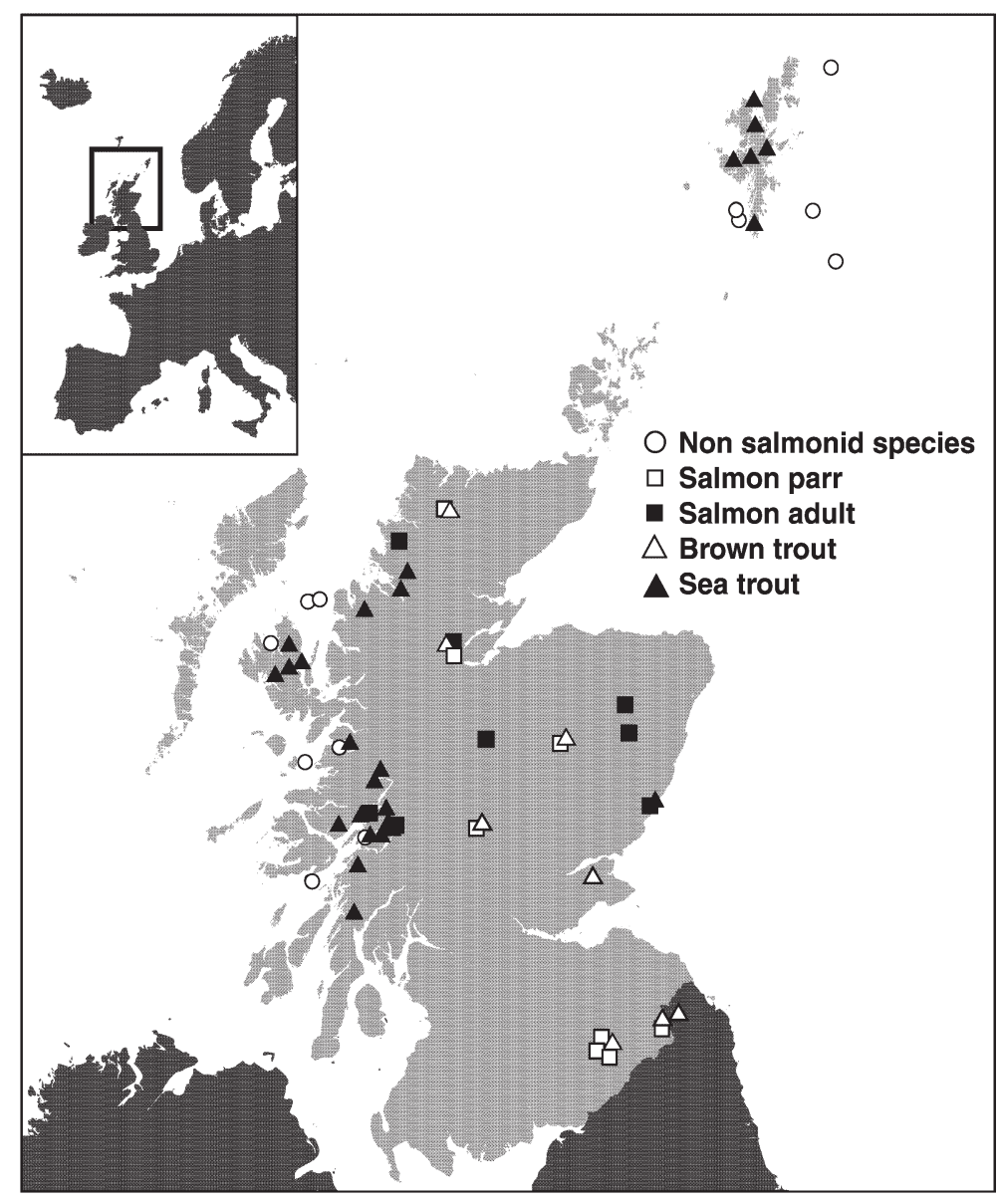

Fig. 1. Map of Scotland showing the locations where fish were sampled during the survey 
Table 2. Results of the ISA diagnostic tests

\begin{tabular}{|c|c|c|c|}
\hline Fish group tested & $\begin{array}{l}\text { No. of fish } \\
\text { tested }\end{array}$ & $\begin{array}{l}\text { Results of ISA } \\
\text { RT-PCR }\end{array}$ & $\begin{array}{l}\text { Results of ISA } \\
\text { virus isolation }\end{array}$ \\
\hline Non-salmonids & 1447 & All negative & All negative \\
\hline Adult salmon & 212 & 9 fish positive & All negative \\
\hline Salmon parr & 211 & $\begin{array}{l}5 \text { out of } 44 \text { pools } \\
\text { tested positive }\end{array}$ & All negative \\
\hline Brown trout & 134 & $\begin{array}{l}5 \text { out of } 29 \text { pools } \\
\text { tested positive }\end{array}$ & All negative \\
\hline Sea trout & 203 & 5 fish positive ${ }^{a}$ & 5 fish positive ${ }^{a}$ \\
\hline
\end{tabular}

from the estuary of the River Snizort and 4 out of 8 sea trout tested from the River Inverie at Loch Nevis were positive by RT-PCR. The juvenile brown trout were negative for ISAV isolation, but brown trout from 3 locations (5 out of 17 pools tested at the 3 locations) tested positive by ISA RT-PCR. All adult salmon and salmon parr tested negative for ISAV isolation. However, parr sampled from 2 locations (4 out of the 11 pools tested at these 2 locations) and 9 out of 30 adult salmon from the River Blackwater tested positive by RTPCR (see Fig. 2 for location). sampled which gave positive results are shown in Fig. 2. None of the fish showed gross pathology associated with ISA and appeared normal. All 1447 nonsalmonid fish tested ISAV-negative by RT-PCR and virus culture. ISA virus was isolated from 5 out of 10 sea trout tested from Laxo Voe, Shetland. Tissues from these fish tested negative by RT-PCR. One sea trout

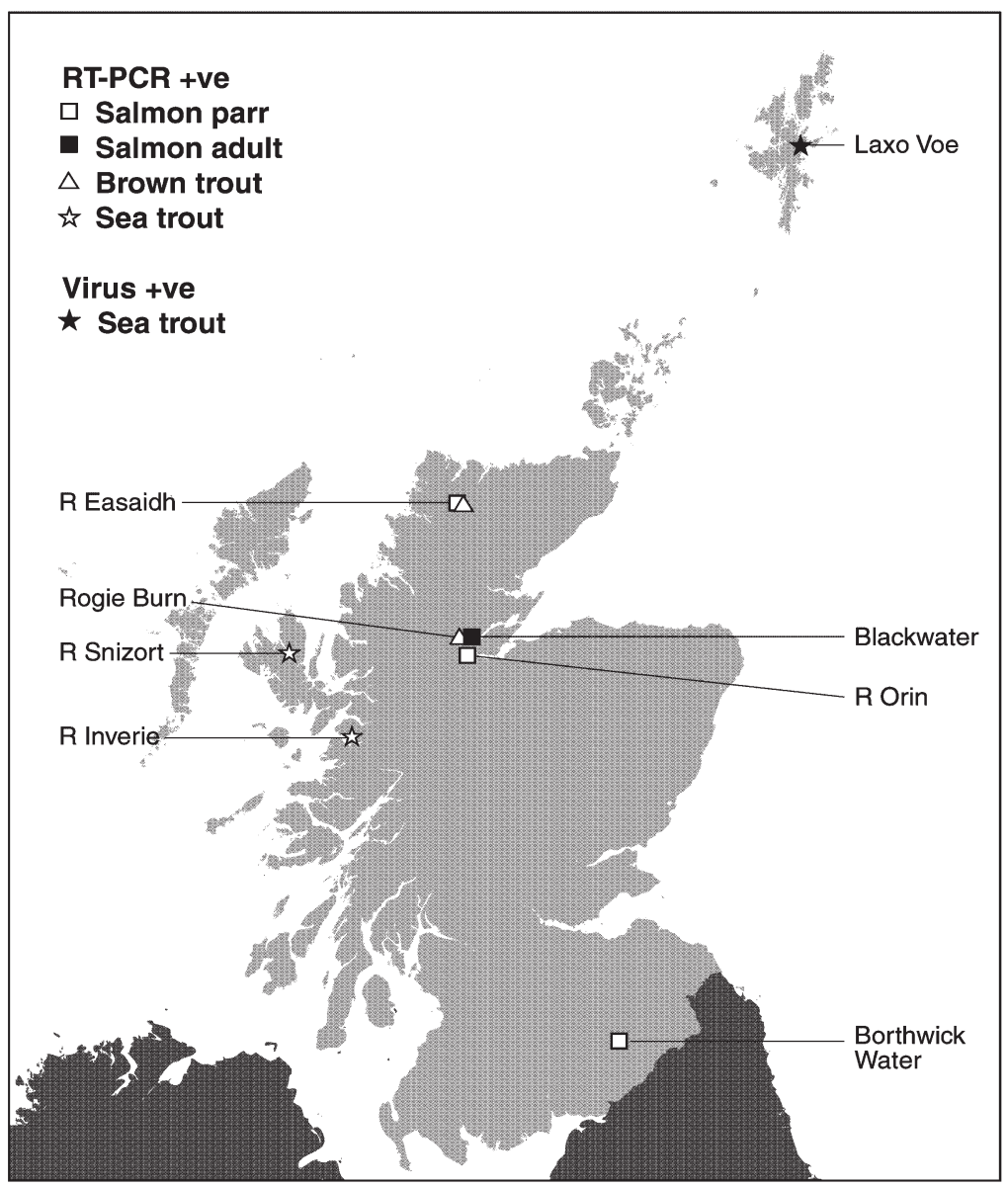

Fig. 2. Map of Scotland showing the locations of fish from which ISA virus isolations were made or which provided positive (+ve) results with the ISA RT-PCR test

\section{Modelling the distribution of ISA RT-PCR results}

The distribution of positive RT-PCR results among salmonid fish is spatially non-random. Brown trout and salmon (adult and parr) show a pattern of occasionally large numbers of positive samples against a background of very low numbers. The best description of the data was obtained by applying a model in which $13 \%$ of the fish are RT-PCR positives in $32 \%$ of the samples with $0 \%$ in the remaining samples (Fig. 3)

We first assumed a random distribution of ISAV, i.e. all fish from all the samples are equally likely to be ISAVpositive. If we assumed $1.55 \%$ of the fish are RT-PCR-positive, then we obtained the observed ISAV prevalence, i.e. 8 of 58 samples, but only 11 fish were RT-PCR-positive, which is far too few. If we assumed $3.87 \%$ of the fish are RT-PCR-positive, then we obtained the observed number of positive fish 27.7, which is the value estimated from the 24 observed positive pools, but prevalence at 15 samples is then too high. Neither matched the full range of observations well, with standard errors of 1.6 and 1.12 respectively, this discrepancy between fitting to the number of samples that are RT-PCR-positive and fitting to the number of RT-PCR-positive fish indicates uneven distribution of ISA RT-PCR among samples.

Therefore, the model applied has a simple uneven distribution in which only a fraction of the environments from which the samples were taken contain ISA. A value of $32 \%$ of samples in which $13.08 \%$ of the fish are RT-PCR-positive 


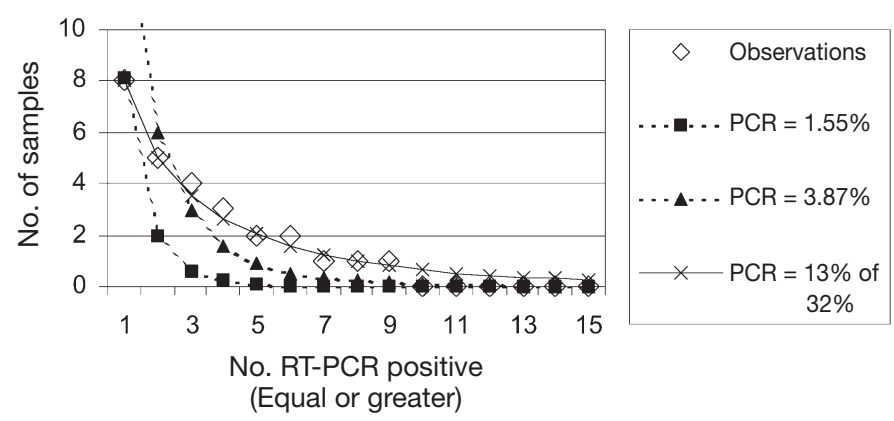

Fig. 3. Observed and modelled distributions of RT-PCR-positive fish. Results are the number of samples that contain the given number of RT-PCR-positive fish or greater. Three models are $1.55 \%$ fish RT-PCR-positive, $3.87 \%$ RT-PCR-positive and $13.08 \%$ RT-PCR-positive but only of $36 \%$ of the samples. A datum of 14.5 samples that contain at least 1 RT-PCR-positive fish under the $3.87 \%$ infection model has been excluded from the figure. The standard errors of the models with respect to the observations have been calculated over the range of $\geq 1$ to $\geq 11$ RT-PCR positives. The SE values are 1.12, 1.6 and 0.32 samples for the 3 models $(3.87,1.55$ and $13 \%$ of $32 \%$ )

in this $32 \%$ was fitted. This gave 30.3 fish with 8 RT-PCR-positive samples, which are both close to the observations. And overall the curve fits the observations well, resulting in a standard error of 0.34 .

RT-PCR-positive fish were only recovered from $13.8 \%$ of the samples while the model suggests $32 \%$ of sampled sites are positive, indicating that approximately half the areas predicted to be RT-PCR-positive and that were sampled were not diagnosed RT-PCRpositive. This discrepancy is because sample size was often too small to ensure detection; for example, RTPCR-positive results were obtained in only $4 \%$ of the 25 samples that consisted of 1 to 5 fish ISA. Samples of over 17 fish were required to give a $90 \%$ chance of detecting RT-PCR-positive area and 22 fish to give a $95 \%$ chance of detection, given that $13 \%$ of the fish were RT-PCR-positive in the ISAV containing areas. These required sample sizes can only be determined after the fact and will not necessarily apply in other circumstances.

\section{Sequence analysis}

Sequence analysis of segments 8 and 2 of ISAV isolates of sea trout from Laxo Voe revealed 100\% sequence homology with isolate 390/98. Analysis of segment 8 of ISAV obtained from kidney of sea trout from the River Snizort, salmon parr from Rivers Easaidh and Orin, adult salmon from River Blackwater and brown trout from Rogie Burn revealed 100\% homology with ISAV isolate 390/98. Sequence analysis of brown trout from the River Easaidh revealed 2 nucleotide differences in segment 8 compared to isolate 390/98. Since differences were observed for segment 8 , segment 2 was sequenced with a further 7 nucleotide differences observed.

Putative protein sequences were predicted from segment 8 and segment 2 of ISAV from brown trout from the River Easaidh. Amino acid sequence predicted from segment 8 differed from the predicted sequence of 390/98 at 2 positions. Neither change in amino acid represented a change of amino acid character (Table 3). The predicted amino acid sequence of segment 2 differed from 390/98 at 5 positions (Table 3). One of these changes, from aspartic acid in the farmed isolate to methionine in the wild brown trout sample, resulted in a change of character of amino acid from acidic to hydrophobic.

\section{DISCUSSION}

This paper reports the first isolation of ISAV in wild fish from Scotland with the isolation of ISAV from sea trout in Shetland. The sea trout from which isolations were made appeared to be in normal health. This would be consistent with experimental findings that brown trout and sea trout show no clinical signs of disease when challenged with ISAV (Nylund \& Jakobsen 1995, Nylund et al. 1995). The sea trout at Laxo Voe carrying ISAV were caught in seawater at the end of June 1999 and had spent time at sea. Sea trout have been shown experimentally to be capable of acting as long-term carriers and to be potential vectors of ISAV (Nylund \& Jakobsen 1995). Sea trout can move up to $126 \mathrm{~km}$ in the Scottish marine environment and return to freshwater to spawn (Gibson \& Ezzi 1990). Therefore, sea trout infected with ISAV could play a role in

Table 3. The amino acid differences between the Scottish farmed isolate (390/98) and brown trout from the River Easaidh (1322-2/99), predicted from the nucleotide sequences of segments 2 and 8 of ISAV. All changes were conservative except at position 259 where the amino acid changed from acidic to hydrophobic in character

\begin{tabular}{|llr|}
\hline \multicolumn{2}{|c|}{ Amino acid change $(390 / 98 \rightarrow 1322-2 / 99)$} & Position \\
\hline Segment $\mathbf{2}$ & & \\
Leucine & $\rightarrow$ Isoleucine & 69 \\
Leucine & $\rightarrow$ Tryptophan & 258 \\
Aspartic acid & $\rightarrow$ Methionine & 259 \\
Isoleucine & $\rightarrow$ Tryptophan & 628 \\
Valine & $\rightarrow$ Methionine & 649 \\
Segment 8 & & \\
Arginine & $\rightarrow$ Lysine & 92 \\
Methionine & $\rightarrow$ Isoleucine & 118 \\
\hline
\end{tabular}


the transmission of ISA in Scotland. The nucleotide sequences of segments 2 and 8 from these sea trout isolates were identical to isolate 390/98 made from the farm outbreak at Loch Nevis. The origin of the ISAV found in the sea trout is not known although there are several possibilities. It is possible that the wild fish were infected from stocks of farmed salmon. Laxo Voe is 84 and $98 \mathrm{~km}$ from the nearest 2 salmon farms affected by ISA. Another possibility is that there is a source of ISAV in wild fish.

In addition to virus isolations from sea trout, positive results from ISA RT-PCR and isolations of at least 1 segment of the ISAV genome were made from Atlantic salmon, brown trout and sea trout from several locations. The successful amplification and subsequent analysis of sequence data from segments 2 and 8 , made from fish tissues, make it very likely that ISAV is the source of the positive RT-PCR findings.

The ability to amplify, by RT-PCR, segments 2 and 8 from fish while not being able to make virus isolations has several possible explanations. It is considered that contamination of the RT-PCR samples is unlikely because RNA was extracted from each sample separately and in isolation with reproducible results. In addition, the nucleotide substitutions in segments 2 and 8 from the River Easaidh brown trout sample do not match sequences from any strains worked on in our laboratory, providing good evidence that contamination did not occur for this sample. An alternative explanation for the absence of virus isolations is the difference in sensitivity between the techniques. RT-PCR has generally proven to be the most sensitive technique to detect ISAV when compared to cell culture and IFAT (Devold et al. 2000, Optiz et al. 2000). However, Kibenge et al. (2000) have reported that cell culture was more sensitive than RT-PCR. Another possible explanation is that ISAV could be causing low level infection so that the samples taken for cell culture did not contain a sufficient quantity of virus for successful isolations. This theory is supported by the RT-PCR results obtained in this study. Although a standard, optimal concentration of RNA was used in reverse transcription, low yields of viral DNA were obtained following amplification by RT-PCR, which may indicate a low level infection. Devold et al. (2000) also found that cell culture was not sensitive enough to be used for isolation and diagnosis of ISAV in carrier trout. Further possible explanations are that virus may have been neutralised by antibodies, which would influence the ratio of infective and non-infective particles, or that there are avirulent forms of ISAV.

ISAV isolations were made from 5 separate sea trout that provided negative results by RT-PCR. Sea trout are known to be long-term carriers of ISAV (Nylund \& Jacobsen 1995); however, the distribution of virus in the organs of carrier trout is not known. It is possible that ISAV is not distributed through all organs in carrier trout and that the quantity of virus may vary between tissues. Interestingly, Devold et al. (2000) reported that ISAV was not detected from kidney of carrier sea trout by cell culture until $135 \mathrm{~d}$ post challenge, and only after inoculation with prednisoloneacetate to stimulate the production of a high number of viral particles (Devold et al. 2000). The virus isolations attempted in this study used a homogenate of heart, kidney, liver and spleen, which may explain why a successful isolation was possible in this case. Devold et al. (2000), however, did report the detection of ISAV by an alternative RT-PCR method to that used in this study, from kidney of experimentally infected carrier sea trout. The signals detected by electrophoresis were of significantly lower intensity than those observed in ISA-diseased salmon (Devold et al. 2000), which might suggest a very low level of virus present in the kidney of the carrier sea trout. It is possible that the RT-PCR technique used in this study was not sensitive enough to detect ISAV in the kidney of the carrier trout. Indeed, there does appear to be variation in the sensitivity of the different RT-PCR methods used to detect ISAV and in whether or not cell culture is more sensitive than RT-PCR (Devold et al. 2000, Kibenge et al. 2000, Optiz et al. 2000). Clearly, an experimental study to determine the distribution of ISAV in the tissues of long-term carrier trout could be performed. Such a study will provide important information on which organs and techniques prove the most reliable in detecting ISAV in carrier fish.

Genetic analysis of segments 2 and 8 of ISAV from sea trout revealed identical or close homology with the Scottish farmed isolate (390/98) of ISAV. The degree of homology between the wild and farmed samples is not surprising, given the close genetic relationship between Scottish farmed and Norwegian farmed isolates. Scottish segments 2 and 8 (AJ242016 and AJ242808) are between 97 and $99 \%$ similar to the Norwegian segments (AJ012285 and AJ002475) (Cunningham \& Snow 2000). In our study, variation was found between ISAV from freshwater brown trout and the Scottish farmed isolate (390/98). Although this result was obtained from 1 sample, the RT-PCR was repeated and at least 4 sequencing reactions were performed on each RT-PCR product. The chromatograms were examined carefully to ensure the differences were not ambiguous. Therefore, it was concluded that the differences observed were genuine. Although the nucleotide differences were minor, they did result in 5 amino acid substitutions in segment 2 and 2 substitutions in segment 8. Previous studies comparing segments 2 and 8 from Scotland, Norway and Canada have revealed similar nucleotide and amino acid changes (Cunning- 
ham \& Snow 2000, Inglis et al. 2000). Since, the sequences of segments 2 and 8 from ISAV in all the farms involved in the epizootic in Scotland were identical (Inglis et al. 2000), the nucleotide substitutions in the brown trout sample from the River Easaidh demonstrate that it is unlikely that this virus originated from the epizootic. The genetic information available from segments 2 and 8 does not provide information on the virulence of this strain. Recent studies have reported the characterisation of 2 further segments, encoding the nucleoprotein (Snow \& Cunningham 2001) and the hemagglutinin (Rimstad et al. 2001). The analysis of the hemagglutinin gene of ISAV from wild fish would be particularly interesting because it contains a variable region that may be very useful for epidemiological and phylogenetic analyses (Rimstad et al. 2001). Such analysis may also provide evidence as to whether or not wild fish can carry avirulent strains of ISAV.

Some of the RT-PCR findings in this study were made from freshwater locations with no direct connection with the west coast of Scotland, Shetland and Orkney, where the marine salmon farms affected by ISA were located (R. Stagg pers. comm.). Thus ISAV may be distributed more widely than originally thought, in areas distant to marine salmon farms and in more than 1 strain. The adult salmon that tested positive by RT-PCR at 1 location had been held as broodstock and had spent several months in freshwater before testing. Whether these adult salmon had become infected before or after entry to the river is unknown. Tagging studies show that Scottish and Norwegian fish share feeding grounds around The Faroes (Anonymous 1986), and a portion of Scottish fish also share feeding grounds around Greenland with fish from Canada and the USA (Moller Jensen 1980). The proximity and extent of contact of fish within shoals is not known, but it is possible that mixing of stocks could contribute to the transmission of ISAV which may be present in oceanic Atlantic salmon. Cross infection of salmon in the high seas could enable ISAV to be transmitted widely. Atlantic salmon that escaped from farms can also be considered as a source of ISAV since there are many reports of these straying from aquaculture sites into the Scottish stocks of wild salmon (Webb et al. 1993, Youngson et al. 1997). ISAV was isolated from 1 escaped salmon caught along the Scottish west coast in 1999 (authors' unpubl. data). The number of escapes during 1999 is not known, but for the first 9 mo of 2000 it is estimated that $400000(0.5 \%)$ fish escaped from marine salmon farms in Scotland (Fisheries Research Services unpubl. data).

This study provides evidence that ISAV was present in wild juvenile Atlantic salmon and brown trout in freshwater. There is only one report of ISA occurring in freshwater where links to seawater seem an unlikely source of virus (Nylund et al. 1999) with an outbreak of ISA in first feeding Atlantic salmon fry at a Norwegian hatchery. The source of the virus was not known, but it was argued that ISA virus could have entered the hatchery through an unknown route rather than vertical transmission especially as there is evidence that eggs were disinfected. The only connection between the Norwegian hatchery and seawater was the eggs from brood fish although Melville \& Griffiths (1999) suggest the absence of a vertical transmission route for ISAV infection. The significance of the RT-PCR findings in freshwater fish in the present study and whether infection causing clinical disease could develop is not known. There have been no reports of wild salmon showing signs of disease. However, while sick fish are easy to identify and retrieve among farmed salmon, it would probably be difficult to find sick wild salmon for reasons discussed by McVicar (1997). It is likely that, in addition to the presence of the virus, specific environmental or host conditions are required in order for clinical disease to develop. It is also possible that the RT-PCR findings could be produced from an avirulent strain of ISAV that does not cause mortality.

This study shows that ISAV was present in wild populations of salmonid fish in Scotland during the period May 1998 to December 1999, although their origin and pathogenicity is unclear. Modelling the distribution of RT-PCR results indicates that ISAV was distributed non-randomly and concentrated at hot spots and that all of the positive RT-PCR results were obtained from only $32 \%$ of the samples. About half of the samples that would be expected to be RT-PCR-positive were not diagnosed because sample sizes were too small. If the detection level by RT-PCR is less than $100 \%$, then the estimate provided by the model, of $13 \%$ of the fish from $32 \%$ of the samples being positive for virus, will be an underestimate. The period of the study is too short to indicate whether ISAV infections will be maintained in wild fish populations or whether prevalence of ISAV in wild and farmed fish is linked. The isolation and sequencing of further segments of ISAV, and a more extensive survey of wild salmonids for ISAV within Scotland, are currently being undertaken. This will help assess the level to which ISAV is present in wild fish, the degree of genetic variation between temporally and geographically distinct populations and whether ISA is endemic.

Acknowledgements. This survey was conducted with the assistance of many organisations and individuals concerned with wild fisheries including District Salmon Fishery Boards, Fisheries trusts, River proprietors, Staff of the FRS Freshwater Laboratory and Aquaculture and Aquatic Animal Health programme. Their help is gratefully acknowledged. 


\section{LITERATURE CITED}

Anonymous (1986) Report of the working group on North Atlantic Salmon. International Council for the Exploration of the Sea, Copenhagen, CM 1986/Assess:17

Blake S, Bouchard D, Keleher W, Opitz M, Nicholson BL (1999) Genomic relationships of the North American isolate of infectious salmon anaemia virus (ISAV) to the Norwegian strain of ISAV. Dis Aquat Org 35:139-144

Bouchard D, Keleher W, Opitz M, Nicholson BL (1999) Isolation of infectious salmon anaemia virus (ISAV) from Atlantic salmon in New Brunswick, Canada. Dis Aquat Org 35:131-137

Bricknell IR, Bruno DW, Cunningham CO, Hastings TS, McVicar AH, Munro PD, Raynard RS, Stagg RM (1998) Report on the first occurrence of Infectious Salmon Anaemia (ISA) in Atlantic salmon (Salmo salar) in Scotland, United Kingdom. 3rd Int Symp Aquat Anim Health, Baltimore, USA, 30 August-3 September 1998. APC Press, Baltimore, MD

Cunningham CO, M Snow (2000) Genetic analysis of infectious salmon anaemia virus (ISAV) from Scotland. Dis Aquat Org 41:1-8

Dannevig BH, Falk K, Namork E (1995) Isolation of the causal virus of infectious salmon anaemia (ISA) in a long-term cell line from Atlantic salmon head kidney. J Gen Virol 76: 1353-1359

Devold M, Krossøy B, Aspehaug V, Nylund A (2000) Use of RT-PCR for diagnosis of infectious salmon anaemia virus (ISAV) I carrier sea trout Salmo trutta after experimental infection. Dis Aquat Org 40:9-18

Evensen O, Thorud KE, Olsen YA (1991) A morhological study of the gross and light microscopic lesions of infectious anaemia in Atlantic salmon (Salmo salar). Res Vet Sci 51:215-274

Falk K, Namork E, Dannevig BH (1998) Characterisation and applications of a monoclonal antibody against infectious salmon anaemia virus. Dis Aquat Org 34:77-85

Gibson RN, Ezzi IA (1990) A comparative study of sea trout (Salmo trutta L.) in west Highland sea lochs with special reference to Loch Feochan. In: Picken MJ, Shearer WM (eds) The sea trout in Scotland. Natural and Environmental Research Council, Swindon, p 61-70

Hovland T, Nylund A, Watanabe, K, Endresen C (1994) Observations of infectious salmon anaemia virus (ISAV) in Atlantic salmon, Salmo salar L. J Fish Dis 17:291-296

Inglis J, Bruce J, Cunningham C (2000) Nucleotide sequence variation in isolates of infectious salmon anaemia virus (ISAV) from Scotland and Norway. Dis Aquat Org 43: 71-76

Kibenge FSB, Whyte SK, Hammell KL, Rannie D, Kibenge MT, Martin CK (2000) A dual infection of infectious salmon anaemia (ISA) virus and a togavirus-like virus in ISA of Atlantic salmon Salmo salar in New Brunswick, Canada. Dis Aquat Org 42:11-15

Krossøy B, Hordvik I, Nilsen F, Nylund A, Endresen C (1999) The putative polymerase sequence of infectious salmon anaemia suggests a new genus within the orthomyxoviridae. J Virol 73:2136-2142

Lovely JE, Dannevig BH, Falk K, Hutchin L, MacKinnon AM, Melville KJ, Rimstad E, Griffths SG (1999) First identification of infectious salmon anaemia virus in North America

Editorial responsibility: Jo-Ann Leong,

Corvallis, Oregon, USA with haemorrhagic kidney syndrome. Dis Aquat Org 35: 145-148

McVicar (1997) The development of marine environmental monitoring using fish diseases. Parasitologia 39:177-181

Melville KJ, Griffiths SG (1999) Absence of vertical transmission of infectious salmon anaemia virus (ISAV) from individually infected Atlantic salmon Salmo salar. Dis Aquat Org 38:231-234

Mjaaland S, Rimstad E, Falk K, Dannevig BH (1997) Genomic characterisation of the virus causing infectious salmon anaemia in Atlantic salmon (Salmo salar L.): an orthomxyo-like virus in a teleost. J Virol 71:7681-7686

Moller Jensen J (1980) Recaptures from the International Tagging Experiment at West Greenland. Rapp P-V Reun Cons Int Explor Mer 176:122-135

Mullins JE, Groman D, Wadowska D (1998) Infectious salmon anaemia in salt water Atlantic salmon (Salmo salar L.) in New Brunswick, Canada. Bull Eur Assoc Fish Pathol 18: $110-114$

Nylund A, Jakobsen P (1995) Sea trout as a carrier of infectious salmon anaemia virus. J Fish Biol 45:174-176

Nylund A, Alexandersen S, Rolland JB, Jakobsen P (1995) Infectious salmon anaemia virus (ISAV) in brown trout. J Aquat Anim Health 7:236-240

Nylund A, Krossøy B, Watanabe K, Holm JA (1996) Target cells for the ISA virus in Atlantic salmon (Salmo salar L.). Bull Eur Asoc Fish Pathol 16:68-72

Nylund A, Krossøy B, Devold M, Aspehaug V, Steine NO, Hovland T (1999) Outbreak of ISA during first feeding of salmon fry (Salmo salar). Bull Eur Assoc Fish Pathol 19: $70-74$

Optiz HM, Bouchard D, Anderson E, Blake S, Nicholson B, Keleher W (2000) A comparison of methods for the detection of experimentally induced subclinical infectious salmon anaemia in Atlantic salmon. Bull Eur Assoc Fish Pathol 20(1):12

Rimstad E, Mjaaland S, Snow M, Mikalsen AB, Cunningham CO (2001) Characterisation of the infectious salmon anaemia virus genomic segment that encodes the putative hemagglutinin. J Virol 75:5352-5356

Rodger HD, Turnbull T, Muir F, Millar S, Richards RH (1998) Infectious salmon anaemia (ISA) in the United Kingdom. Bull Eur Assoc Fish Pathol 18:115-116

Snow M, Cunningham CO (2001) Characterisation of the putative nucleoprotein gene of ISAV. Virus Res 74(1-2): 111-118

Stagg R, Bruno D, Cunningham C, Hastings T, Bricknell I (1999) Infectious salmon anaemia in Scotland: epizootiology and pathology. State Vet J 9:1-5

Thorud K, Djupvik H (1988) Infectious anaemia in Atlantic salmon (Salmo salar L.). Bull Eur Assoc Fish Pathol 8: $109-110$

Turnbull T (1999) Infectious salmon anaemia in the United Kingdom. Fish Vet J 3:64-67

Webb JH, Youngson AF, Thompson CE, Hay DW, Donaghy M J, Mclaren IS (1993) Spawning of escaped farmed Atlantic salmon, Salmo salar L., in western and northern Scottish rivers: egg deposition by females. Aquac Fish Manag 5: $663-670$

Youngson AF, Webb JH, MacLean JC, Whyte BM (1997) Frequency of occurrence of reared salmon in Scottish salmon fisheries. ICES J Mar Sci 54(6):1216-1220

Submitted: January 26, 2001; Accepted: May 23, 2001

Proofs received from author(s): September 4, 2001 